\title{
The Affecting Factors Towards The Continuity of Academic Administration Management System at State University of Medan (UNIMED)
}

\author{
Yan Azhari \\ Department of Educational Management \\ Faculty of Educational Management \\ State University of Medan \\ Medan, Indonesia \\ Corresponding email: azhariyan@gmail.com \\ H. Syaiful Sagala \\ Lecturer of Medan State University \\ Medan, Indonesian
}

\begin{abstract}
This study aims to analyze: the dominant factors that affect the academic administration management system, the weight of the dominant factors towards the continuity of academic administration management system as well as the unique factors which significantly influence the continuity of academic administration management system at Unimed. The population of this study is the students of Regular Education Program in the academic year of 2006 with a total of 2,100 students. The proportional random sampling technique uses Harry King's Nomogram method with determined confidence level of $95 \%$ and is obtained from 240 respondents. The type of the research is ex post facto which reveals facts based on the measurement of symptoms that have already existed in the respondents themselves. The result of the data analysis is analyzed using factor analysis statistical technique, the abstraction results of 13 variables form three dominant factors with eigenvalues greater than 1 namely: basic obedient, policy makers, and regulations. The weight of the factors gives significant influence to the continuity of academic administration management system at Unimed. Based on the correlation of matrix coefficient, it is found that the unique factor of tolerance has a significant influence on the academic administration system by paying attention to: basic obedient, policy makers, and regulations which are the main foundation. Therefore, the developed system will not lose the existence and nature of the benefits of the system development.
\end{abstract}

Keywords-Dominant factors; system management; academic administration.

\section{INTRODUCTION}

In reaching the objective of Unimed, information system is utilized as parts of the development of the university in becoming a modern campus in the service of the Three Pillars of Higher Education. The role of the information system in improving the performance of higher education is becoming very crucial nowadays due to the complexity of the activities and varieties of related stakeholders as well as the increasing numbers of student. The information system is the tool which is able to support the problem-solving activities faced by the users of it [1].

Due to the many factors that can affect the academic administration management system around Unimed, this study is limited to the dominant affecting factors of the effectivity and continuity of the management system viewed from the students' perception towards the activity at Unimed. Specifically, the factors are the Students' Activities Factor, the System, the Policy Makers (Decision Makers), and the Regulations.

Problems that will be reviewed in this study are (a) what are the dominant factors in the implementation of academic administration management system at Unimed? (b) Does the weigth of the dominant factors give significant influence towards the continuity of the academic administration management system? (c) Is there any unique factor which has a significant effect towards the continuity of the academic administration management system at Unimed?

The problems encountered in the academic administration management system are often solved partially instead of being viewed systematically which covers the whole components. This is a less appropriate action because the academic administration system has a very wide and varieties of interrelatedness. The academic administration management system is greatly influenced by the management system in a whole, which in this case including the decision makers, financial administration system, academic administration system, and regulations. The complexity of the problems can 
be simplified by identifying the dominant factors using the concept of factor analysis.

Factor analysis is one of the procedures of data reduction in multivariate statistical technique. It is related to the structure identification of a group of observation variables, in which each of it contains one or more initial variables (manives variables). Those new variables are called laten variable and are fewer than the manives variables. Factor analysis is the main analysis method related to the strength, flexibility and proximity to the nature of the intention and purpose of the study. Moreover, it is said that factor analysis is used to serve the purpose of the efficiency of scientific activities since it can reduce the double test and measurement, which make it far more simpler. A factor is a construct which is considered underlying the test, scale, points and even almost any type of size [2].

Each system contains components which are interrelated in a whole. There is a special characteristic in each system [3]. A stronger system approach to the procedure is that a system is a work web of interconnected procedures, gathering together to do an activity or to complete a particular target [4].

School as a system is arranged by components including context, input, process, output, and outcome [5], which can be analogized that academic administration is a system which consists of context, input, process, output, and outcome.

The Acadmeic Adminstration System is a sytem which manages the data and run the process of academic activity which involves the students, lecturers, academic administration, finance, and other attributes of data. The Academic Administration is made of several components [6].

The Academic Regulation is the whole regulations which ties up the elements in the education implementation system. In increasing and stabilizing the academic administration system, especially towards the acceleration and accuracy of the academic data circulation among components or academic organization units at Unimed, a Governance of Academic Administration Activity at Unimed and the Students' Study Load Setting are set based on the law issued by the government, including the Laws, Government Regulations, Decision of the Ministry of Education and the Decisiion of the Director General of Hihger Education as well as the Statute of State University of Medan. The decision making is a process of choosing an alternative action among many which affect the future.

The purposes of the study are to (1) know the dominant factors in the academic administration management system at Unimed, (2) the weight of dominant factors in giving significant influence towards the continuity of the academic administration management system, (3) determine the unique factor which has significant influence towards the continuity of academic administration management system at Unimed.

A dominant factor is a main factor in the academic administration management system which functions as the derminant in the implementation. It gives significant influence towards the continuity of the academic administration management system around Unimed.
The emergence of unique factors in the academic administration management system has affected the development of it in giving space for the development to stay reliable and qualified along with the development of the Information Communication and Technology (ICT).

By finding the dominant factors in the implementation of the academic administration management system will reduce the obstacles occurred along the time. Furthermore, the weight of the dominant factors gives significant influence in solving the problems encountered in managing the academic administration data of the students at Unimed.

The unique factor in the implementation of the academic administration management system has an effect towards the continuity of the system management. A continuity process of academic administration management system will accelerate the students' study completion.

The arragement of eigenvalues are always sorted fom the the largest to the smallest with a record number below 1 not used in calculating the number of factors formed Table 1.

An academic administration management system is a system which consists of several subsystems starting from the acceptance of the students until the study completion, including the transcript making, diploma printing as well as the Adjustment Certificate (AKTA). In each subsystem, there are numerous factors found. These factors and the total of the factor weight can be seen in Table 2 .

The hypothesis of this study can be forlmulated as follows: (1) Basic Obedience, Policy Makers, and Regulations are the dominant factors in the academic administration management system at Unimed. (2) Basic Obedience, Policy Makers, and Regulations have significant capacity towards the continuity of the academic administration management system (3) There is a unique factor which has significant influence towards the academic administration management system at Unimed.

From the result of factors analysis through SPSS media version 13.0 obtained three factors which is a summary of the 13 variables analyzed there is:

Table 1.

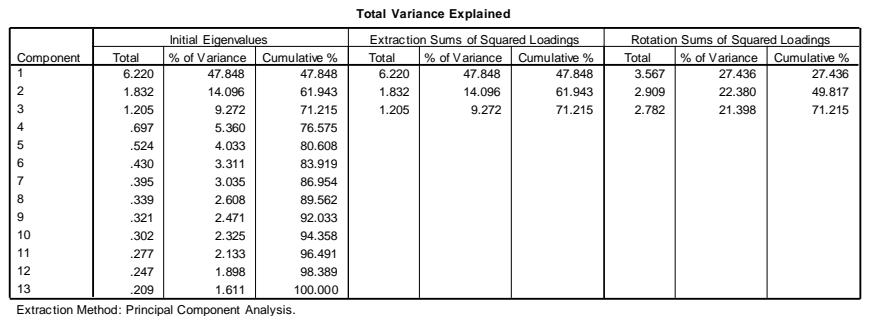


Table 2.

Rotated Component Matrix(a)

\begin{tabular}{|c|c|c|c|}
\hline & \multicolumn{3}{|c|}{ Component } \\
\hline & F1 & $\mathrm{F} 2$ & F3 \\
\hline B1 & .834 & .159 & .118 \\
\hline A3 & .818 & .102 & .191 \\
\hline A2 & .810 & .120 & .257 \\
\hline B2 & .742 & .321 & .149 \\
\hline A1 & .702 & .112 & .214 \\
\hline B4 & .067 & .894 & .012 \\
\hline B3 & .417 & .718 & .096 \\
\hline $\mathrm{C} 4$ & .149 & .647 & .547 \\
\hline $\mathrm{C} 1$ & .293 & .634 & .376 \\
\hline $\mathrm{C} 2$ & .068 & .630 & .557 \\
\hline D1 & .216 & .167 & .840 \\
\hline D2 & .332 & .005 & .785 \\
\hline $\mathrm{C} 3$ & .232 & .429 & .717 \\
\hline
\end{tabular}

Extraction Method: Principal Component Analysis.

Rotation Method: Varimax with Kaiser Normalization.

a Rotation converged in 6 iterations.

Table 3.

Koefisien Korelasi

\begin{tabular}{|l|c|c|c|c|c|c|c|c|c|c|c|c|c|}
\hline & B1 & A3 & A2 & B2 & A1 & B4 & B3 & C4 & C1 & C2 & D1 & D2 & C3 \\
\hline B1 & & & & & & & & & & & & & \\
\hline A3 & 0.628 & & & & & & & & & & & & \\
\hline A2 & 0.626 & 0.700 & & & & & & & & & & & \\
\hline B2 & 0.719 & 0.556 & 0.601 & & & & & & & & & & \\
\hline A1 & 0.512 & 0.583 & 0.592 & 0.512 & & & & & & & & & \\
\hline B4 & 0.180 & 0.159 & 0.175 & 0.312 & 0.194 & & & & & & & & \\
\hline B3 & 0.423 & 0.426 & 0.431 & 0.488 & 0.394 & 0.613 & & & & & & & \\
\hline C4 & 0.275 & 0.337 & 0.351 & 0.380 & 0.315 & 0.534 & 0.544 & & & & & & \\
\hline C1 & 0.423 & 0.343 & 0.405 & 0.511 & 0.269 & 0.514 & 0.518 & 0.606 & & & & & \\
\hline C2 & 0.228 & 0.272 & 0.308 & 0.310 & 0.280 & 0.506 & 0.471 & 0.667 & 0.573 & & & & \\
\hline D1 & 0.315 & 0.366 & 0.372 & 0.329 & 0.352 & 0.219 & 0.370 & 0.552 & 0.446 & 0.520 & & & \\
\hline D2 & 0.357 & 0.378 & 0.445 & 0.409 & 0.340 & 0.122 & 0.287 & 0.432 & 0.425 & 0.374 & 0.663 & & \\
\hline C3 & 0.393 & 0.338 & 0.427 & 0.437 & 0.373 & 0.392 & 0.422 & 0.677 & 0.550 & 0.687 & 0.653 & 0.540 & \\
\hline
\end{tabular}

Tabel 4.23 Faktor Utama hasil Reduksi faktor pada SPSS Analyses

\begin{tabular}{|l|l|l|}
\hline \multicolumn{1}{|c|}{ Faktor 1} & \multicolumn{1}{c|}{ Faktor 2} & \multicolumn{1}{c|}{ Faktor 3 } \\
\hline B1.Software (0.834) & B4.Mekanisme (0.894) & D1.T. Laksana Akad. (0.840) \\
\hline A3.Asas Waktu (0.818) & B3.Jaringan (0.718) & D2.Beban Belajar (0.785) \\
\hline A2.Asas Aturan (0.810) & C4.Inkonsisten (0.647) & C3.Negosiasi (0.717) \\
\hline B2. Hardware (0.742) & C1.Konsisten (0.634) & \\
\hline A1.Asas Kewajiban (0.702) & C2.Fleksibelitas (0.630) & \\
\hline
\end{tabular}

\section{RESEARCH METHODOLOGY}

This stuy was conducted at Unimed Jl. Iskandar Psr. V Medan Estate on students of Year 2006 starting from November 2008 until February 2009. The population of this study was the students of Regular Educational Program 2006 Academic Year with a total of 2.100 students.

Proportional Random Sampling was used in taking samples. The size of the sample was based on the Harry King Nomogram $(\mathrm{N}=\leq 2000)$ with its confidence interval set to $95 \%$ so that the total of the sample acquired nmin $=12 \% \mathrm{x}$ $2.000=240$ samples (results of Harry King Nomogram reading, $\alpha=5 \%$ ). From this amount, it was assumed that there were $95 \%$ observable samples with prediction of $95 \%$ of the data could be processed (Warwich dan Lininger). Therefore, the expected size of the sample was:

$$
n=\frac{240}{0.95 \times 0.95}=265.93 \text { rounded to } 265
$$

This study was an ex post facto type of stuy. In order to obtain a well implemented Academic Administration System, it should be viewed from (1) the Students' Activities Factor, (2) System Factor, (3) Policy Makers, and (4) Regulations.

Before the data analysis was done, an Assumption Test was first done towards the research data including the ormality Test and Variant Homogenity. Normality Test was done to find out whether the research data distribution of each variable had spread out normally by using the Chi-Quadran Statistic, while the Variant Homogenity Test was done by applying the Bartlette Test.

The statistic data analaysis being used in this study was factor analysis. Factor analysis is one of the data reduction procedures in the multivariate statistic technique. Factor analysis is related to the structure identification of a group of observation variables, in which the correlation among the variables will be used to form new variables where each of it consists of one or more initial variable (manives variable). The new variable is called as laten variable and is not as many as the manives variable.

As a method, factor analysis has a set of steps or processes. There are four important steps, which are the correlation matrix, factor load, rotation, and factor interpretation.

The formula being used for the bivariate analysis correlation, the correlation among the research variables, is as follows:

$$
r=\frac{N \Sigma X Y-(\Sigma X)(\Sigma Y)}{\sqrt{\left\{\left(N \Sigma X^{2}-(\Sigma X)^{2}\right)\left(\Sigma Y^{2}-(\Sigma Y)^{2}\right)\right\}}}
$$

Note:

$\mathrm{r}=$ correlation coefficient between $\mathrm{x}$ and $\mathrm{y}$

$\mathrm{N}=$ total of respondents

$$
\text { Hyphotesis test }=\text { T-test }
$$

$$
t=\frac{\sqrt[r]{n-2}}{\sqrt{1-r^{2}}}
$$

$\mathrm{H}_{0}$ is rejected if: $\mathrm{t}>\mathrm{t}_{\left(1-\frac{1}{2} \alpha\right)}$ or $\mathrm{t}<-\mathrm{t}_{\left(1-\frac{1}{2} \alpha\right)}$ with $\mathrm{dk}=$ $(\mathrm{n}-2)$

$$
\begin{aligned}
& \mathrm{n}=\text { total data (sample size) } \\
& \mathrm{r}=\text { correction coefficient }
\end{aligned}
$$

A matrix is a random number (or sign) structuring system in a form of a square. The correlation matrix is always in squares and symmetries. The lower half of the matrix under the diagonal (from the upper left to the bottom right) is equal to its upper half. This means that the coefficients in the lower half are identical with those in the upper half, with different structuring only.

The determination of the total number of the factors is based on how big the eigenvalue of each emergin factor. The main factors chosen are the ones which have the eigenvalue $>1$. 
To solve the problems and other problems due to the large number of factors, an objective method is needed in order to set the total of factors, factor tests, as well as the weight of the factors. This can be written as aij, which means the load of a on $\mathrm{i}$ test towards the $\mathrm{j}$ factor. The range of the factor load starts from $-1,00$ to 0 to $+1,00$, similar to the correlation coefficient which shows the correlation among the tests and factors

Factor analysis rotation helps to ease the data interpretation. The purpose of the rotation is to decide one simple structure. It means that in each factor, no zero factors loading are expected for every variable. The rotation does not influence the fit factor. It redistributes the explanation of the variant for the individual factor.

The rotation method can be used in accordance with the purpose expected to reach, which is orthogonal namely: varimax, equamax, quartimax, or oblique such as direct oblimin (SPSS V13).

Thurstone in [2] gives some instructions in doing the factor rotation, which is to set 5 principles or simple structure that are applied for both vertical (orthogonal or 90 degree angle) and nonvertical rotation ( if the angle formed by two axis is acute/obtuse). The concepts of simple structure are: (1) each row of the factor matrix should have at least one zero or near zero loading (2) each column of the factor matrix should have at least one zero or near zero loading variables with the same number of factors (3) for every pair of columns, there should be several zero loadings in one column corresponding to nonzero loadings in the other column (4) when four or more factors are obtained, most variables should have ignored loadings (near zero loadings) into distinct pair of factors (5) for every pair of factors (column) in the factor matrix should have the column. Under these circumstances, pure variables are required as many as possible, this means that every variable contains as few factors as possible and as many zero loadings as possible in the rotated factor matrix [2]. This research is conducted using varimax rotation. It is an orthogonal method which tries to minimize the number of variables with high loading to a factor, thus it helps to make an interpretation about a factor.

\begin{tabular}{|c|l|l|l|}
\hline & f1 & f2 & f3 \\
\hline X1 & & & \\
\hline X2 & & & \\
\hline X3 & & & \\
\hline X4 & & & \\
\hline X5 & & & \\
\hline X6 & & & \\
\hline X7 & & & \\
\hline X8 & & & \\
\hline X9 & & & \\
\hline X10 & & & \\
\hline X11 & & & \\
\hline X12 & & & \\
\hline X13 & & & \\
\hline
\end{tabular}

Figure 1. Factor Load
Interpretation of factor is drawn by grouping the variables with high factor loading to the factor itself. The minimal factor loading interpretation for this research is 0.55 . Variables whose value is less than 0.55 are rejected.

\section{FINDINGS AND DISCUSSION}

The result of the analysis and hypothesis testing includes the following:

\section{A. Finding 1}

There are several dominant factors in the practice of academic administration management system at UNIMED, they are:

1) The 1st factor is Basic obedient. This is due to the obedience shown by the variables representing this factor. The obedience is needed in undertaking the system created based on the existing software and hardware. Basic obedience factor is the most affecting factor towards the academic administration management system because of its highest eigenvalue 6.220. These variables consist of software, basic time and rules, hardware and basic obligation which are able to demonstrate the variant diversity as $47.848 \%$. Measured from the factor loading, software contributes to the highest value to form basic obedient with its loading factor 0.834 . This is to show that the software is obedient because the designed software will remain consistent to receive determined inputs. On the other hand, if the input does not match to the software regulations, the software will reject the inappropriate data (based on the program logic). Basic time variable contributes to the 2 nd highest factor loading with 0.818 and then followed by basic rules (0.810) as well as hardware and basic obligation (0.742 and 0.702 respectively).

2) The 2nd factor is Policy Makers. It is due to the variables representing this factor show the attitude of policy makers towards the existing system. This is as the 2nd most affecting factor which affects the academic administration management system around UNIMED because of its eigenvalue 1.832. The variables in this factor consist of mechanism, networking, inconsistent, consistent and flexibility. These variables could demonstrate the variant diversity to $14.096 \%$. Measured from the factor loading, mechanism is the most contributing variable with its factor leading 0.894. This shows that the regularity mechanism in conducting the academic administration management system can be fulfilled so that the attitude of policy makers can be directed to the existing mechanism. Networking contributes to the 2nd highest factor loading with 0.718 and followed by inconsistent variables with its loading factor to 0.647 as well as consistent and flexibility variables $(0.634$ and 0.630 respectively).

3) The 3rd factor is named as Regulations because the variables representimg this factor indicates a binding rule needs to be implemented in conducting the 
academic administration management system. Regulation is the 3rd affecting factor towards the academic administration system management around UNIMED due to its eigenvalue 1.205. The variables in this factor consist of several variables, such as: academic management, study load and negotiation in which these factors could demonstrate the variant diversity as $9.272 \%$. Measured from the factor loading, academic management shows the highest factor leading with 0.840 which then indicates that the process of academic administration management system must still be run under the written regulations in an official document. This is then followed by the other variables namely study load and negotiation with their factor loadings 0.785 and 0.717 respectively.

These three factors are the dominant factors towards the continuity of academic administration management system at UNIMED. Based on the basic consept, a system is a unit of components or elements which are connected together to ease the flow of information, material or energy. A system is a work web of interconnected procedures and gathered to perform an activity or to solve particular target (Jerry Fitzgerald, Ardra F. Fitzgerald dan Warren D. Stallings, Jr.). A system approach which is the work web emphasizes more to the sequence of operations within the system. This, then, points out that every component or subsystem in the academic administration system should not be out of the sequence (systematic approach).

In the scope of a system definition, there are numerous components (elements) and activities (the function of every component), mutual relationship and integration (organic unity) between components, a wide range of system (the internal and external area of the system) and the dynamic move of all functions of components leads to the achievement of predetermined system, in this case, to achieve the continuity of academic administration system at UNIMED. The previous research [7] has already discussed a critical point that every activity procedures towards the academic administration system in terms of the involvement and work flow involve a number of units or work units. For that reason, coordination and communication are needed in every activity. Coordination, as the way to unite actions, ideas, thoughts, and suggestions towards the collective goals, has not yet been well-achieved due to the violation of rules, procedures, work plans and policy which have been set by a leader.

\section{B. Finding 2}

Based on the analysis and hyphothesis testing, it is found that the dominant factors contribute significantly to the continuity of academic administration management system at UNIMED.

The result of the three dominant factors is: Basic obedient, Policy Makers and Regulations. Those are the determined (significant) factors of the continuity of academic administration management system at UNIMED. This, eventually, could be explained that the basic obedient, the attitude of policy makers and regulations are the basic principles of the continuity of academic administration management system at UNIMED. The well-established and well-designed academic administration system will result to the improper practice of the system if the users are disobedient in following the system mechanism. This proves that no matter how well-established a system and a regulation is, it will not result to the continuity of the system. On the other hand, if the users are obedient enough to follow the system, the continuity of academic administration management system could be achieved. This has also explained that [8] computer based education management gives positive and significant contribution towards the effectiveness of working performance of administration officers'.

\section{Finding 3}

There are unique factors which also significantly affect the continuity of academic administration management system at UNIMED.

The number of variants contributed by a variable to another variable (communality) as well as the covariation within the elaborated variables will cause to the appearance of the fewer amounts of common factors, which are (1) Basic obedient, (2) Policy makers, (3) Regulations. Furthemore, besides the three dominant factors, there are other factors which also play an important role in the academic administration management system at UNIMED, namely the unique factors.

The first unique factor is the covariation of academic management variable (D1) with its inconsistent variable (C4) is 0.522 and flexibility variable $(\mathrm{C} 2)$ is 0.520 . The second unique factor is the covariation of negotiation variable (C3) with its inconsistent variable (C4) 0.677 , consistent variable (C1) 0.550 and flexibility variable (C2) 0.687 . This indicates that the intersection of variables of academic management and negotiation contribute to the appearance of regulations and policy makers factors.

The first unique factor is the covariation of academic management variable (D1) with its inconsistent variable (C4) is as 0.522 and flexibility variable $(\mathrm{C} 2)$ is as 0.520 . The second unique factor is the covariation of negotiation variable (C3) with its inconsistent variable $(\mathrm{C} 4)$ is as 0.677 , consistent variable $(\mathrm{C} 1)$ is as 0.550 and flexibility variable $(\mathrm{C} 2)$ is as 0.687. This indicates that the intersection of variables of academic management and negotiation contribute to the appearance of regulations and policy makers factors. This also shows that in running the process of academic administration system at UNIMED, it should refer to the guide book which contains the academic management and study load regulations. The rules that have been made should be the reference. However, in some cases, they can be tolerated in order to solve the current problems so that they do not disturb the continuity of the academic administration system. This can be seen from several cases, such as: (1) students who are late paying tuition would be given an opportunity to complete the payment, (2) students who are late to record their study plan card would be given an opportunity, (3) students who are in their 14th semester are allowed to have 26 credits of semester.

The appearance of these unique factors is when the existence of toleration factors do not disturb the effectiveness or continuity of the academic administration system at UNIMED, in this case, if the toleration factor is $0.5 \%$. 


\section{CONCLUSION AND RECOMMENDATION}

\section{A. Conclusion}

The findings of this research are:

1) There are 3 dominant factors which affect the continuity of academic administration system at UNIMED, they are: (1) Basic Obedient. This is the 1st dominant factor appeared from the software, basic time and rules, hardware and basic obligation. (2) Policy Makers. This is the 2nd dominant factor appeared from the mechanism networking, inconsistent, consistent and flexibility variables. (3) Regulations. This is the 3rd dominant factor appeared from the academic management, study load and negotiation variables.

2) The weight of the dominant factors gives significant impact towards the continuity of the academic administration management system at UNIMED.

3) There are several unique factors which have significant effects towards the continuity of the academic administration management system at UNIMED.

\section{B. Recommendation}

State University of Medan could maintain or even improve the academic administration management system by revising the variables which are not yet considered important. However, the appearance of dominant factors could not be ignored because they contribute significantly to the process of the continuity of students' academic administration management system. This would eventually cause to the effective academic administration service which then could enhance the process of students' study completion. The tendency to develop a hightechnology system would be nothing if the dominant factors are rejected. This situation could be proven when we see the well-developed and well-supported high-technology system could not run effectively if the users are disobedient and have no commitment towards the policy markers as well as do not follow the regulations so that the technology which at first could help handling the academic administration system management will not contribute significantly towards the continuity of the administration management system. Then, the development strategy of the higher institution by adopting and anticipating the growing needs and demands cannot be fulfilled. The academic administration mechanism after being analysed using factor analysis can bee seen in Figure 2 .

The academic administration mechanism at UNIMED consists of three main components, they are: (1) Registration, (2) Lectures, (3) Study completion.

Registration component consists of several subcomponents, namely: (1) tuition payment, (2) lectures schedule, (3) students conselling, (4) lecturer job description, (5) record of study plan card, (6) study plan card print out.

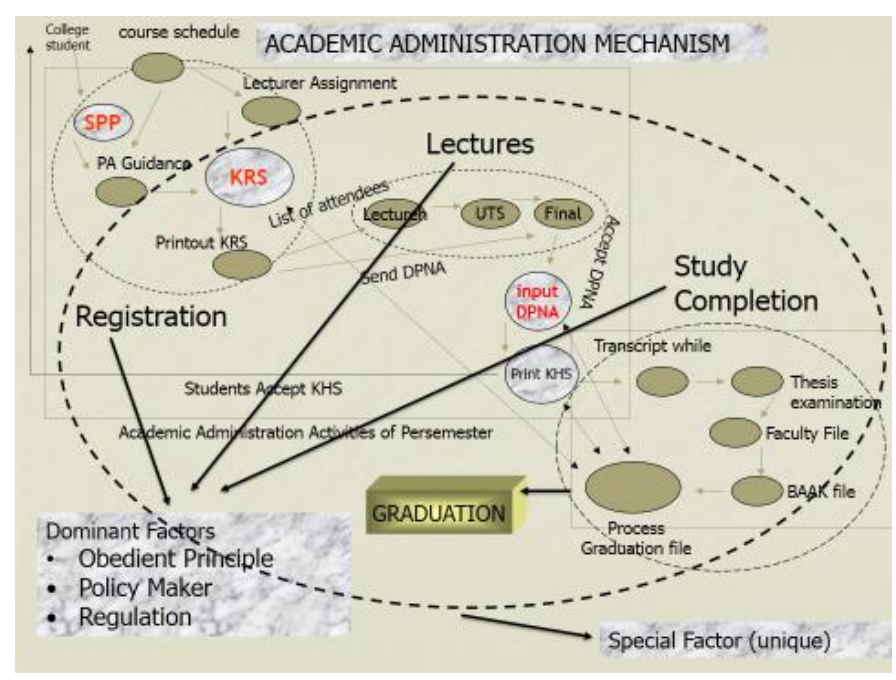

Figure 2. Academic Administration Mechanism

Lecture component consists of several subcomponents, namely: (1) instructional activity, (2) monthly test, (3) final text, (4) the input of marks, (5) students' study result.

Study completion component consists of some subcomponents, such as: (1) temporary transcript, (2) thesis examination, (3) faculty documents, (4) BAAK documents, (5) graduation documents process.

Finally, of all the three main components, there are three dominant factors and unique factors for each component

\section{REFERENCES}

[1] Siagian, Sondang P. (2003). Sistem Informasi untuk pengambilan keputusan. Jakarta: Gunung Agung

[2] Kerlinger, F. N. 1990. Asas-asas Penelitian Behavioral. Yogyakarta: Gadjah Mada University Press.

[3] Taneko, Soleman B. 1986. Konsepsi Sistem Sosial dan Sistem Sosial Indonesia. Jakarta: Fajar Agung.

[4] Jerry FitzGerald, Ardr F. FitzGerald, Warren D. Stallings, Jr. 1981. Fundamentals of Systems Analysis (edisi kedua; New York: John Willey \& Sons.). hal. 5.

[5] Slamet PH, 2005. Kapita Selekta Desentralisasi Pendidikan di Indonesian. Handout Proyek Desentralisasi Pendidikan Dasar. Jakarta: Direktorat Pendidikan Lanjutan Pertama (Depdiknas).

[6] Buku Pedoman Universitas Negeri Medan Tahun Akademik 2007/2008

[7] Herawan (1999) "Penyalenggaraan Sistem Administrasi Akademik di Lingkungan Perguruan Tinggi Negeri (Studi Tentang Proses Penyelenggaraan Sistem Administrasi Akademik di IKIP Bandung dan Universitas Padjadjaran)".

[8] Hidayat, 2016. "Manajemen Kantor Pendidikan Berbasis Teknologi Komputer Kontribusinya Terhadap Efektivitas Kerja Pegawai Administrasi di Universitas Pendidikan Indonesia (UPI)". 